Article

\title{
Superheated Steam Torrefaction of Biomass Residues with Valorisation of Platform Chemicals Part-2: Economic Assessment and Commercialisation Opportunities
}

\author{
Baharam Roy ${ }^{1}\left[\right.$, Peter Kleine-Möllhoff ${ }^{2, *} \mathbb{C}$ and Antoine Dalibard ${ }^{3}$ \\ 1 Reutlingen Research Institute (RRI), Reutlingen University, 72762 Reutlingen, Germany; \\ roybaharam@gmail.com \\ 2 ESB Business School, Reutlingen University, 72762 Reutlingen, Germany \\ 3 Fraunhofer Institute for Interfacial Engineering and Biotechnology IGB, 70569 Stuttgart, Germany; \\ antoine.dalibard@igb.fraunhofer.de \\ * Correspondence: peter.kleine-moellhoff@reutlingen-university.de; Tel.: +49-712-1271-5009
}

check for

updates

Citation: Roy, B.; Kleine-Möllhoff, P.; Dalibard, A. Superheated Steam Torrefaction of Biomass Residues with Valorisation of Platform Chemicals Part-2: Economic Assessment and Commercialisation Opportunities. Sustainability 2022, 14 , 2338. https://doi.org/10.3390/ su14042338

Academic Editor: Ana Ramos

Received: 3 February 2022

Accepted: 16 February 2022

Published: 18 February 2022

Publisher's Note: MDPI stays neutral with regard to jurisdictional claims in published maps and institutional affiliations.

Copyright: (C) 2022 by the authors. Licensee MDPI, Basel, Switzerland. This article is an open access article distributed under the terms and conditions of the Creative Commons Attribution (CC BY) license (https:// creativecommons.org/licenses/by/ $4.0 /)$.

\begin{abstract}
Up to now biorefinery concepts can hardly compete with the conventional production of fossil-based chemicals. On one hand, conventional chemical production has been optimised over many decades in terms of energy, yield and costs. Biorefineries, on the other hand, do not have the benefit of long-term experience and therefore have a huge potential for optimisation. This study deals with the economic evaluation of a newly developed biorefinery concept based on superheated steam (SHS) torrefaction of biomass residues with recovery of valuable platform chemicals. Two variants of the biorefinery were economically investigated. One variant supplies various platform chemicals and torrefied biomass. The second variant supplies thermal energy for external consumers in addition to platform chemicals. The results show that both variants can be operated profitably if the focus of the platform chemicals produced is on high quality and thus on the higher-priced segment. The economic analysis gives clear indications of the most important financial influencing parameters. The economic impact of integration into existing industrial structures is positive. With the analysis, a viable business model can be developed. Based on the results of the present study, an open-innovation platform is recommended for the further development and commercialisation of the novel biorefinery.
\end{abstract}

Keywords: biorefinery; superheated steam torrefaction; economic assessment; volatile recovery; platform chemicals; commercialisation

\section{Introduction}

What would our economies look like if we produced exclusively biobased chemical products with renewable resources? Can chemical production plants be operated economically independently of finite fossil raw materials in the sense of a circular economy? Is superheated steam (SHS) torrefaction suitable for the economic production of platform chemicals?

Revenues from circular economy products and services are not yet as profitable as their classic linear-oriented alternatives. Raising venture capital, promoting commercialisation and exporting to international markets are among the key future challenges that circular economy companies will have to face [1-3]. Biorefineries must increase their revenues in order to be competitive and attract future investments. However, the economic performance of biorefineries is influenced by many external factors, such as the development of energy prices, the cost of biomass feedstocks and the change in supplier markets due to changing competitive conditions.

\subsection{Economic Aspects}

Investigations by Ref. [4] show that biorefinery concepts are particularly hampered in their commercialisation by the following economic aspects: necessity of high invest- 
ments, high operating costs, high overall costs, low return of investment, high capital costs, high logistical costs and volatile biomass costs [4]. Raising venture capital, promoting commercialisation and exporting to international markets are further challenges for the bioeconomy $[2,3,5,6]$. As long as biobased products are in direct competition with conventional alternatives, they can only be profitable in niche markets that reward sustainability in terms of price [7] or offer application potentials [8]. On the other side, the changed risk analysis of financial institutions with regard to sustainability supports the acquisition of funds for biorefineries. Business models that require non-renewable raw materials are increasingly excluded from financing [7]. Quality and product differentiation seem to be the preferred strategic response to compete successfully with biorefineries [9]. For instance, Ref. [8] reports on a profitable biorefinery concept for the valorisation of olive oil pomace that can produce high value products while improving the economic and environmental sustainability of the olive oil value chain [8].

From the market side, fluctuating prices of the end products and the raw materials used represent the most important economic challenges for a biorefinery [10]. The markets for bioproducts and biofuels are relatively new and volatile. This has an impact on demand and can significantly affect the selling prices of these products in the market [11].

Most publications assessing the competitiveness of biorefineries refer to the production of biomass fuels or chemicals sold in higher quantities, such as fibres or synthetic fuels. The few examples from the chemical industry show that the switch to circular value chains is preferable via commodity chemicals [12-16].

\subsection{Pilot and Demonstration Scale, Commercialisation}

The majority of biorefinery plants are still under development, at pilot or demonstration scale. Established research does not address the immediate challenges at this level of development. Even the literature on technology and innovation management is scarce in this regard. However, pilot and demonstration scale are important and necessary to raise industrial interests and encourage collaboration between different actors, i.e., industrial companies, academia, public authorities and equipment industry $[17,18]$. Robust biorefinery concepts can only be realised through a multi-layered approach that takes the relationship between biorefinery configurations, economic performance and future uncertainties into account [16]. Aspects of the innovation system in the biorefinery environment that have been weak so far are primarily resource mobilisation and market formation [9]. Therefore, new markets and businesses need to be developed and their potential needs to be assessed. This in turn requires that new market applications are established and new technologies are developed [19]. Ref. [19] conducted an exploratory case study specifically for a biorefinery in Germany. They focused on the company actors and found that the combination of leading actors, learning companies and gap fillers from the SME or start-up sector was an important success factor. Investments in new technologies with long payback periods need to be made by mature industries that have alternative investment opportunities available [9]. Established companies are seen as playing a crucial role in the commercialisation of new technologies because no market entry would take place without an adaptation of their strategies and business models [20]. The presence of "gap fillers" is an indication of partnership-based strategic system-building activities, where suppliers and manufacturers integrate complementary resources to jointly create products and markets [21]. The innovation system must be able to mobilise the necessary resources while creating supply and demand [20].

One of the biggest challenges in terms of commercialising a biorefinery is setting up a biomass supply system that can meet the biorefinery's long-term biomass demand in a cost-effective way. In addition to the fluctuations in the costs of the supply system, the volatilities of the market prices for the produced goods of the biorefinery should not be underestimated [10]. A diversification strategy developed in a network by fully valorising a biomass resource into a range of products with maximum total value, combined with a good business model, can improve the economic feasibility of biorefineries [22]. 


\subsection{Industrial Symbiosis Aspects}

Many of the higher value-added chemical compounds found in biomass residues are present in low quantities. The value proposition must therefore be to maximize the added value of biomass and resource efficiency. This strategy requires cost-effective, cascading biomass utilization that can fully utilize all components [1,23]. The potential for new process combinations has certainly not yet been exhausted and offers considerable market opportunities [7]. Thus, an optimised biorefinery realises maximum cascading value creation throughout the life cycle [24].

Recent studies show that flexibility on the feedstock and integration into existing production networks allows one to increase the economic performance of biorefineries [15,25-27]. Combining biorefinery concepts like torrefaction with other processes such as co-combustion, pyrolysis, gasification or industrial processes to further increase the value of the product outputs makes it more efficient and economical than using it as a stand-alone process $[15,28,29]$. Biorefinery technologies that are thermally integrated with cooperating industries offer opportunities to increase significantly the economic and energetic performance [30,31]. If heat integration is chosen, the optimal production capacity of the biorefinery can be matched to the demand of the consumers in the heat network [16]. However, the capacity of the biorefinery can also be designed in such a way that all biological residues produced by the hosting companies are used as feedstock [32], or the biorefinery production covers the fuel needs of the host firms [33].

For an environmentally friendly and economic use of biomass-residues, it is necessary to develop cross-sectoral valorisation visions [24]. It is therefore important to concentrate on high-quality products on the one hand and to increase the spectrum of products for the solid and liquid fractions obtained on the other [9]. It has been widely discussed in the literature that a diversification strategy and the extraction of a range of products with maximum total value from biomass, combined with a good business model, significantly improves the feasibility of biorefineries in economic terms [20,34,35]. Although research on biomass torrefaction is increasing recently, there is a lack of information on the integration of the technology within an overall biorefinery concept for specific applications [15].

\subsection{Goal, Scope and Structure}

This paper builds on Part 1 of the series, which examines a biorefinery concept under development for the simultaneous production of high-quality biochar and platform chemicals by SHS torrefaction of biobased residues. In the first part of the series, it was shown that the newly developed biorefinery is capable of producing several platform chemicals with a favourable environmental footprint. In this second part of the series, the process is evaluated economically, and the most important economic levers are identified. Based on the economic analysis and the technical possibilities of the investigated biorefinery as well as the state of the art in science, it is furthermore shown which path to commercialisation could be taken.

This publication is structured as follows. First, there is a detailed presentation of the methods and materials used. This is followed by a chapter on the economic analysis of the biorefinery studied. Based on this economic analysis and the state of the art presented in the introduction, a further section is devoted to the derivation of a possible commercialisation strategy. This is followed by a discussion of the economic results and the commercialisation aspects. The results of the work are then briefly summarised in the conclusion.

\section{Materials and Methods}

This study is based on experimental results obtained within a German public-funded research project on an innovative biorefinery concept (see funding section). The economic evaluation of the newly developed biorefinery builds on the process flow diagram as shown in Figure 1, and the material and energy balances developed in part 1 of this publication series. More information on the process steps is given there. The process units with grey background represent the reference case. In addition to this reference case, another variant 
was investigated in which the torrefied biomass is fed to an incineration plant (hatched background and dashed lines) that serves to supply thermal energy to the biorefinery process being investigated and to external consumers. A steam loss of $5 \%$ was considered for each of the two variants, which translates into a corresponding condensate accumulation and product output.

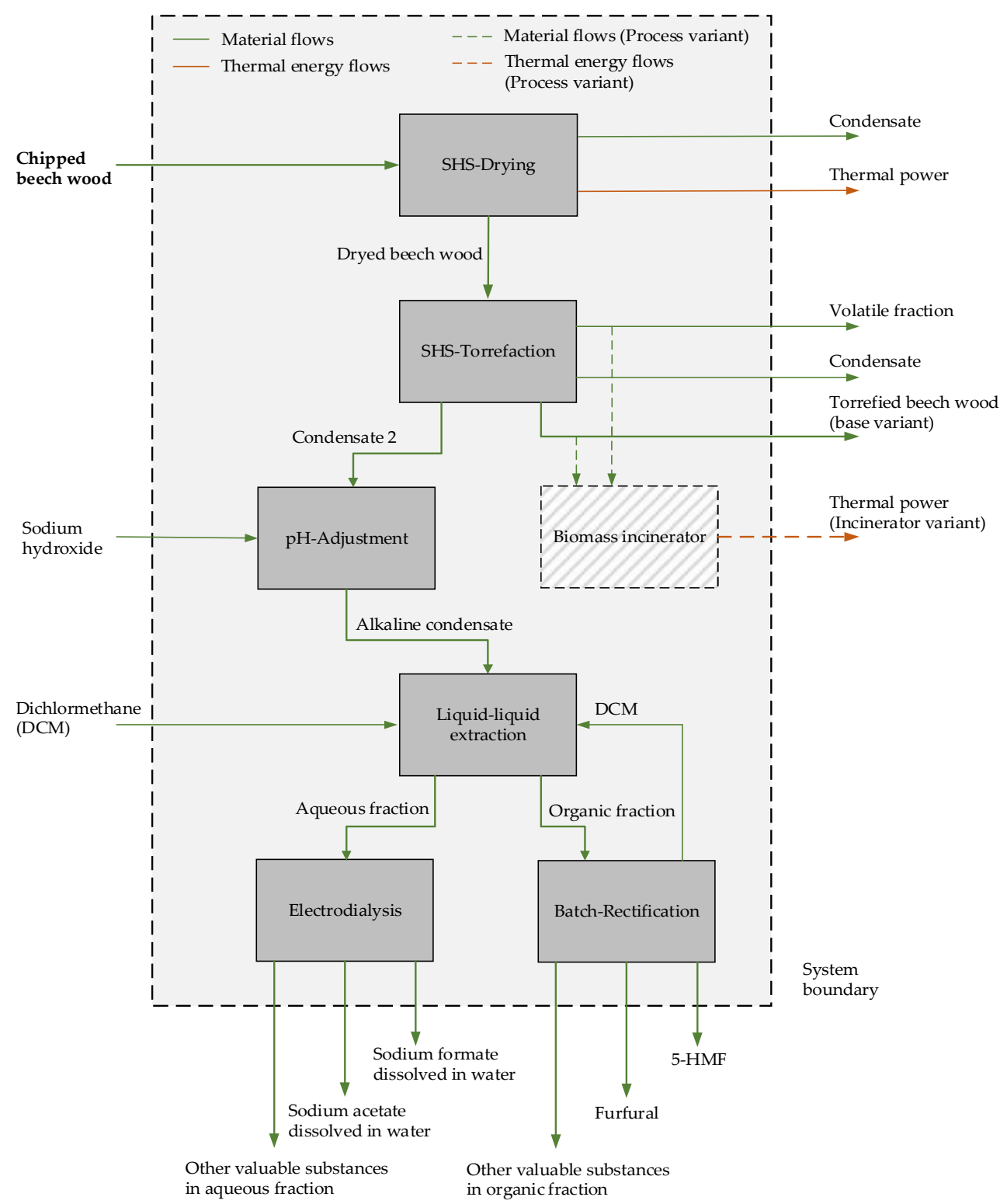

Figure 1. Biorefinery process set up.

Traditional discounted cash flow analysis is often used to provide an indication of how likely it is that an investment will be profitable. However, the shift to biorefinery concepts is a long-term investment and is subject to time uncertainties. The discounted cash flow analysis ignores the possibility for investors to adjust their investment strategy to changing market conditions and is therefore not necessarily suitable for evaluating biorefineries [36], especially when it comes to the flexible production of small quantities with high product quality. For this reason, no discounted valuation method was used for the present investigation.

The economic evaluation was carried out according to the method of [37], which estimates the costs of process plants with an accuracy of $+/-20 \%$ and is based on financial calculation methods in chemical and process plant engineering [38-40]. Table 1 lists 
the assumptions and parameters for the economic analysis. The determination of the investment costs is based on a list of equipment that is developed from the process flow diagram [37] and Part 1 of our publication series in the Materials and Methods section [41], and thus on the mass and energy balance of the biorefinery. For this purpose, the process equipment was dimensioned for an input flow of $1000 \mathrm{~kg} / \mathrm{h}$ of chipped beech wood residue within the scope of this project. Standard apparatuses such as motors, pumps, fans, heat exchangers, silos and conveying elements were queried from suppliers or determined via the internet. Special designs, such as the housings of the drying and torrefaction chambers, but also silos and tanks, were dimensioned, and the steel weights were estimated, by the authors themselves.

Table 1. Assumptions and parameters for the economic analysis.

\begin{tabular}{|c|c|c|c|c|}
\hline Designation & Value & Unit & Description & Source \\
\hline Evaluation model & & & according to references & \multirow{2}{*}{ [37-40] } \\
\hline Accuracy for the investment cost & $+/-20$ & $\%$ & & \\
\hline Design input & 1000 & $\mathrm{~kg} / \mathrm{h}$ & Biomass input & \\
\hline Operating time & 5080 & $\mathrm{~h} / \mathrm{a}$ & & $\begin{array}{c}\text { Authors' } \\
\text { assumption }\end{array}$ \\
\hline Plant location & \multicolumn{4}{|c|}{ Germany } \\
\hline Indirect investment costs & 40 & $\%$ & $\begin{array}{l}\text { of direct investment costs } \\
\left(\text { reference case }{ }^{*}\right)\end{array}$ & \multirow{3}{*}{ [37-40] } \\
\hline Process investment costs & 20 & $\%$ & of direct and indirect & \\
\hline Risk supplement & 15 & $\%$ & (reference case *) & \\
\hline Annual depreciation & 5 & $\%$ & of investment costs & $\begin{array}{l}\text { Authors' } \\
\text { assumption }\end{array}$ \\
\hline Weighted average cost of capital (WACC) & 6.6 & $\%$ & according to reference & [42] \\
\hline Maintenance costs & 3 & $\%$ & \multirow[b]{2}{*}{ of investment costs } & \multirow[b]{2}{*}{ [37-40] } \\
\hline $\begin{array}{c}\text { Property tax, municipal charges, } \\
\text { insurance and license fees }\end{array}$ & 4 & $\%$ & & \\
\hline $\begin{array}{l}\text { Development overheads } \\
\text { and profit margin }\end{array}$ & 10 & $\%$ & \multirow{2}{*}{$\begin{array}{l}\text { of total annual } \\
\text { operation costs }\end{array}$} & \multirow{2}{*}{$\begin{array}{c}\text { Authors' } \\
\text { assumption }\end{array}$} \\
\hline Sales and administrative overheads & 7.5 & $\%$ & & \\
\hline Sensitivity analysis & & & $\begin{array}{l}\text { Material costs } \\
\text { Energy costs } \\
\text { Personnel costs } \\
\text { Product revenues }\end{array}$ & $\begin{array}{l}\text { Authors' } \\
\text { decision }\end{array}$ \\
\hline
\end{tabular}

* for the process variant the absolute costs were estimated.

The material and processing costs were taken from specific sources for normal and stainless steel from $[43,44]$; the raw prices of these components were determined accordingly. All heat exchangers were designed using an online shortcut heat exchanger sizing tool from Ref. [45], and their weights were determined as well. From this, the raw prices of these components were determined for verification purposes using the method described above. This approach had to be taken because the offers were obtained in spring and summer 2021 during the COVID-19 pandemic, and offers with an unusually long delivery time in particular appeared to be overpriced.

The investment costs were determined from the apparatus costs using two different calculation methods. One method called Hand works with multiplication factors for different types of equipment. The other method, the Plant Component Ratio (PCR) method, uses cost distribution factors for equipment and other trades, such as the foundations, instrumentation or piping of a process plant [37-40]. The Hand method adds cost factors 
for indirect investments (e.g., buildings and infrastructure), process investments and risk supplement to the equipment costs to arrive at the total investment costs. The PCR method determines the total investment costs via cost distribution factors between the process engineering apparatus, process design costs, electrical and instrumentation and control technology, construction site costs, etc. [37-40]. Individual cost distribution factors, such as those for process design and construction site costs, were adjusted after the results were provided in order to arrive at realistic values. The absolute process design costs, for example, could be estimated by the authors themselves based on experience developing similar plants. The biorefinery should be constructed from as many standard components as possible, and the individual process units should be delivered to the site completely pre-assembled on frames (skid-mounted) in order to minimise the assembly effort and thus the costs at the construction site. For the process variant, only a completely supplied biomass incineration plant including flue gas cleaning is added in terms of investment. Due to the high additional costs for the incineration plant compared to the biorefinery, the surcharges for the Hand method were adjusted for the total investment costs of the variant so that realistic absolute values are given. The same applies to the variant for the cost allocation factors for the PCR method. Two offers were obtained for the biomass incineration plant and verified with the specific investment costs from Ref. [46]. The mean values for the investment costs were then calculated from the two investment cost methods according to Ref. [37] for the reference case and the process variant with biomass incinerator. These were depreciated over 20 years and assigned to the fixed operating costs. These annual depreciation costs represent the only CapEx factor.

Capital costs, maintenance, laboratory expenses, property taxes, municipal charges, insurance costs and license fees were determined according to Ref. [37] and allocated to fixed operating costs. For the capital costs, the weighted average cost of capital (WACC) for 2019/2020 in Germany according to Ref. [42] has been taken. The personnel costs were determined for the case that the biorefinery is an independent facility and thus must be fully staffed from the managing director to the cleaning staff and the security service. The variable operating costs were determined from the process-related material and energy balances. All costs have been calculated for the location Germany.

According to Ref. [37], research and development costs as well as sales and administration costs were added to the total operating costs to finally obtain the total annual operating costs of the biorefinery in the reference case and the variant with biomass incineration plant.

The total annual costs calculated in this manner were counterbalanced against the total annual revenues from the extracted platform chemicals, the torrefied biomass or, in the case of the process variant with an incineration plant, the sales revenue from the heat generated. Only the products shown in Figure 1 were considered for the revenues.

In addition, it was analysed how the investment costs are distributed over the entire process and which subprocesses represent the biggest cost drivers.

Within the course of a sensitivity analysis, the personnel, material and energy costs as well as the revenues from the platform chemicals, torrefied biomass and thermal energy generated were considered in particular.

A consideration of the cost allocation to the various saleable end products was carried out using the allocation methodology according to the Ref. [47].

A basic eco-efficiency analysis was conducted following references [48-50].

The economic considerations refer to a plant with $1000 \mathrm{~kg} / \mathrm{h}$ input material and an assumed annual operating time of $5080 \mathrm{~h}$ and takes into consideration the development status of the plant. Only the two variants described above were considered. Further considerations, such as the combination with a combined heat and power plant, pyrolysis or synthesis gas production, were not carried out within the scope of this work. In addition, all investigations referred to conditions in Germany.

Based on the results of the economic analysis and the state of the art in science, a proposal for a possible development and commercialisation path was prepared. 


\section{Results}

\subsection{Investment Costs}

Figure 2 shows the investment costs of the reference case and the process variant, which were determined using the Hand and PCR methods. These include all direct and indirect investment costs, risk surcharges, etc., as described in the methodology chapter. Details of the calculation are provided as Supplementary Material. The incineration plant for torrefied biomass represents a considerable additional investment in the process variant. However, it must be taken into account that the incineration plant with boiler and flue gas treatment is a proven technology with low additional risk, which causes significantly lower additional costs in percentage terms with regard to the indirect investments. These inter-relations were considered in the calculations. The two investment cost calculations according to Hand and PCR lead to results that differ by less than 5\% for the two variants examined.

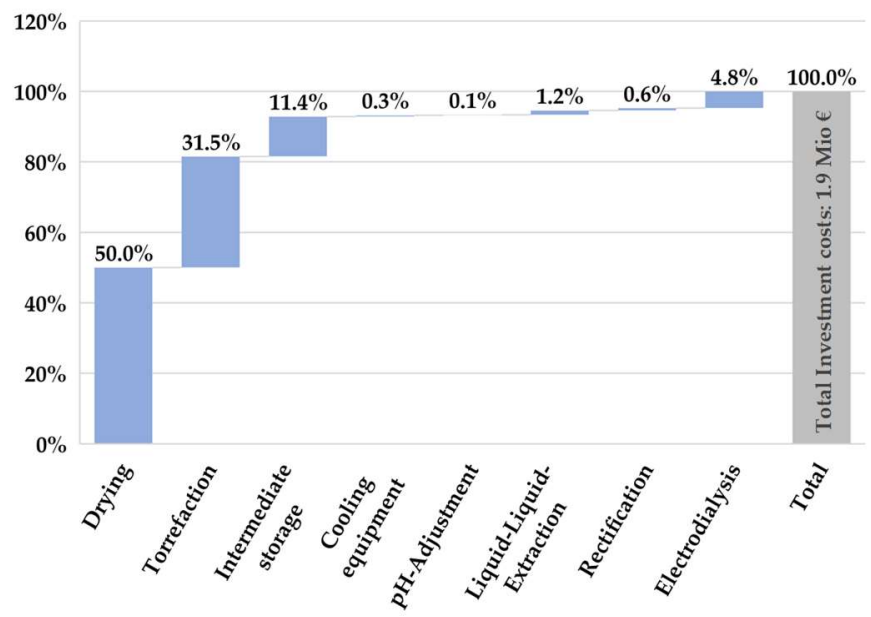

(a)

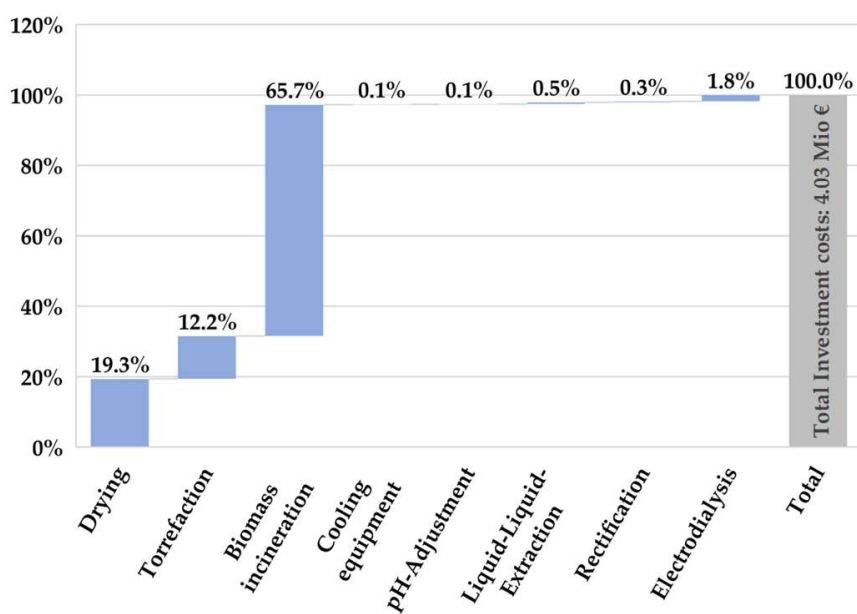

(b)

Figure 2. Investment costs: (a) reference case; (b) process variant.

In the reference case, it becomes clear that the processing units that handle the largest material flows also cause by far the largest investment costs. Dryer and torrefaction account for about $92 \%$ of the total investment. The separation of the different chemicals thus only causes about $8 \%$ of the total investment costs.

In the process variant, the incineration plant with boiler and flue gas treatment accounts for the largest share of costs (approx. 65.7\%), followed by the dryer and torrefaction (approx. 31.5\%). Here, the separation of chemicals accounts for an even smaller share (approx. 3\% in total).

The investment costs are depreciated on a straight-line basis over a 20-year period and then included in the total operating costs.

\subsection{Operating Costs}

Figure 3 shows the total annual operating costs for both variants. These costs do not yet include the surcharges for research and development, profit, sales and administration.

In the reference case, $66 \%$ of the total operating costs have to be spent on fixed costs, and $34 \%$ have to be spent on variable operating costs. In the process variant, $77.5 \%$ are attributable to fixed costs and $22.5 \%$ are attributed to variable costs.

In both variants, personnel costs account for the largest share, followed by the costs for biomass woodchips residues. The energy costs burden the reference case with 10\% and can be significantly decreased to less than $4 \%$ in the process variant with thermal selfsupply. For electricity, a price of 18.25 Eurocents per kWh was used [51], and 3.96 Eurocents per $\mathrm{kWh}$ was used for natural gas [52]. In the process variant, the capital costs of more than $13 \%$ and depreciation of $10 \%$ of the total costs have a considerable impact due to the significantly higher investment costs. All other cost shares are well below $10 \%$. 


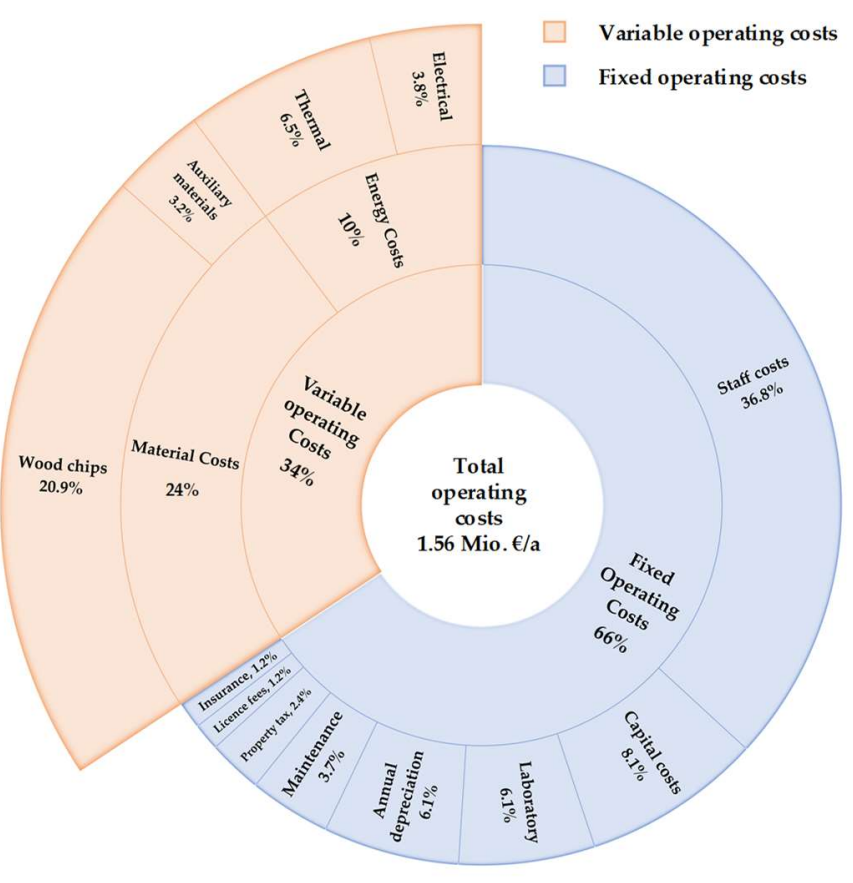

(a)

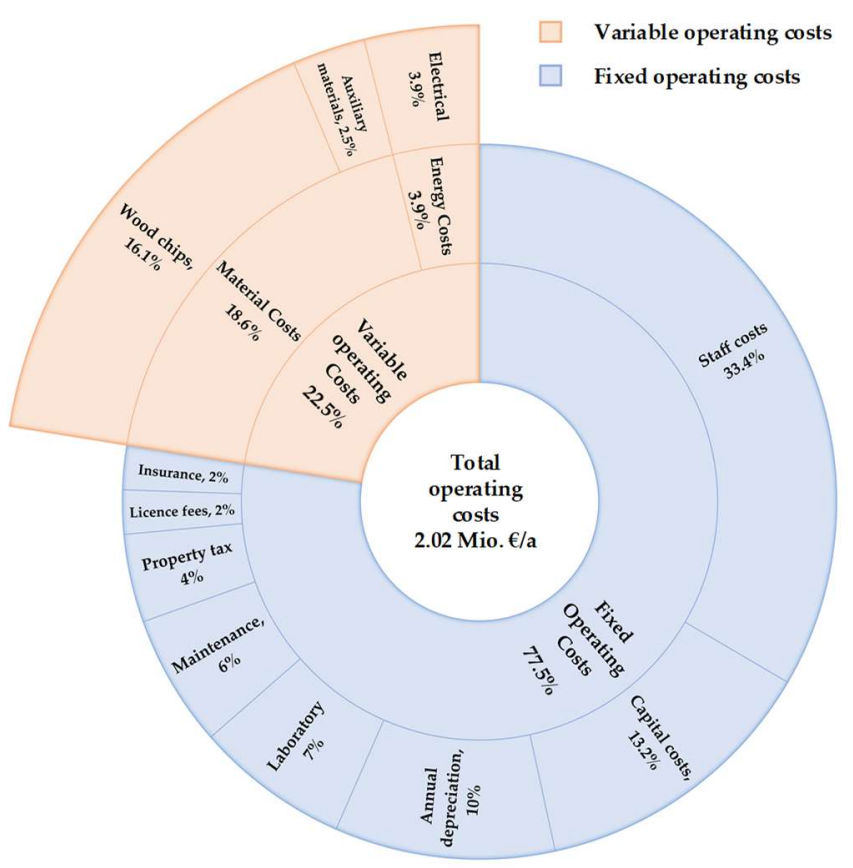

(b)

Figure 3. Annual Fixed and variable operating costs: (a) reference case; (b) process variant.

The total costs for both variants under investigation were then further charged with $10 \%$ for development overhead and profit margin, as well as $7.5 \%$ for sales and administration as indicated in Table 1.

\subsection{Product Revenues and Profitability}

Table 2 lists the products generated with an assumed steam loss of $5 \%$, the market prices found and the revenues calculated from these. The steam loss should be below $1 \%$ in a well designed and constructed plant so that with this conservative assumption, the predicted chemical yields are realistic. The excess thermal energy found in the table represents the thermal surplus energy from the combustion of the torrefied biomass in the process variant after deduction of the plants' own thermal energy demand

Table 2. Product revenues.

\begin{tabular}{|c|c|c|c|c|c|c|c|}
\hline \multirow[b]{2}{*}{ Product } & \multirow{2}{*}{\multicolumn{2}{|c|}{ Amount }} & \multirow{2}{*}{\multicolumn{2}{|c|}{ Market Price }} & \multicolumn{2}{|c|}{ Revenues } & \multirow[b]{2}{*}{ Source } \\
\hline & & & & & Reference & Process & \\
\hline $\begin{array}{c}\text { Torrefied } \\
\text { beechwood }\end{array}$ & 694.85 & $\mathrm{~kg} / \mathrm{h}$ & 0.24 & $€ / \mathrm{kg}$ & $847,161 €$ & & [53] \\
\hline Excess thermal energy & 3812 & $\mathrm{kWh} / \mathrm{h}$ & 0.075 & $€ / \mathrm{kWh}$ & & $1,452,372 €$ & [54] \\
\hline Methanol & 1.169 & $\mathrm{~kg} / \mathrm{h}$ & 0.40 & $€ / \mathrm{kg}$ & $2376 €$ & $2376 €$ & [55] \\
\hline Sodium acetate & 13.459 & $\mathrm{~kg} / \mathrm{h}$ & 6.93 & $€ / \mathrm{kg}$ & $473,820 €$ & $473,820 €$ & [56] \\
\hline Sodium formate & 1.254 & $\mathrm{~kg} / \mathrm{h}$ & 62.39 & $€ / \mathrm{kg}$ & $397,444 €$ & $397,444 €$ & [57] \\
\hline Furfural & 0.830 & $\mathrm{~kg} / \mathrm{h}$ & 21.97 & $€ / \mathrm{kg}$ & $92,584 €$ & $92,584 €$ & [58-60] \\
\hline 5-HMF & 0.052 & $\mathrm{~kg} / \mathrm{h}$ & 1400 & $€ / \mathrm{kg}$ & $369,113 €$ & $369,113 €$ & {$[61]$} \\
\hline Total revenues & & & & & $2,182,497 €$ & $2,787,708 €$ & \\
\hline
\end{tabular}

The market prices for the products extracted essentially depend on the quality and the sales quantities. Because the aim is to serve the market for the extracted chemicals 
with small production quantities and a high product quality, the corresponding prices were taken from the sources mentioned in the table and used as a basis for the calculations. For example, three types of furfural with purity greater than $98 \%$ are available on the mentioned sources. As a result, the market price for furfural is calculated as an average price per kilogramme of furfural. A higher heating value (HHV) of $22 \mathrm{MJ} / \mathrm{kg}$ was assumed for the torrefied biomass produced. In reality, however, this value can be as high as $28 \mathrm{MJ} / \mathrm{kg}$ depending on the feedstock and selected process parameters, resulting in higher revenues. For the thermal energy produced, it was assumed that there are several industrial consumers with different heat demands. A corresponding mixed price was set for the thermal energy delivered.

Market prices for sodium acetate and sodium formate have increased since 2021. The extent to which changed market prices affect the profitability of the plant is examined in the following chapter as part of the sensitivity analysis. For the calculation of profitability, it was assumed that the 10\% cost surcharge for development overhead and profit are each divided $50 \%$ on average over the years of operation.

This results in a profitability of $19.8 \%$ for the reference case and $18.5 \%$ for the variant with biomass incineration. This means that the high investment costs for biomass incineration with the assumptions deteriorated the profitability of the plant by about one percentage point. However, it must also be considered that the calculation of the investment costs with the chosen method results in a target accuracy of plus-minus $20 \%$. Thus, the result for profitability is also subject to a higher uncertainty than the above-mentioned difference regarding the profitability of the reference case and the process variant. For this reason, the cost parameters with the greatest influences were exposed to a sensitivity analysis.

\subsection{Sensitivity Analysis}

Sensitivity analyses were carried out for the cost blocks energy, material, personnel costs and revenues from the sale of the products.

Figure 4a shows the influence of the variation in energy costs on profitability. Given the recent energy price development in 2021, a stronger price increase rather than a price decrease is expected in the future. Therefore, a price escalation of up to plus $50 \%$ was considered. The sensitivity analysis shows that the reference variant in particular is affected by energy price increases in terms of profitability and that this does not drop by more than five percentage points.

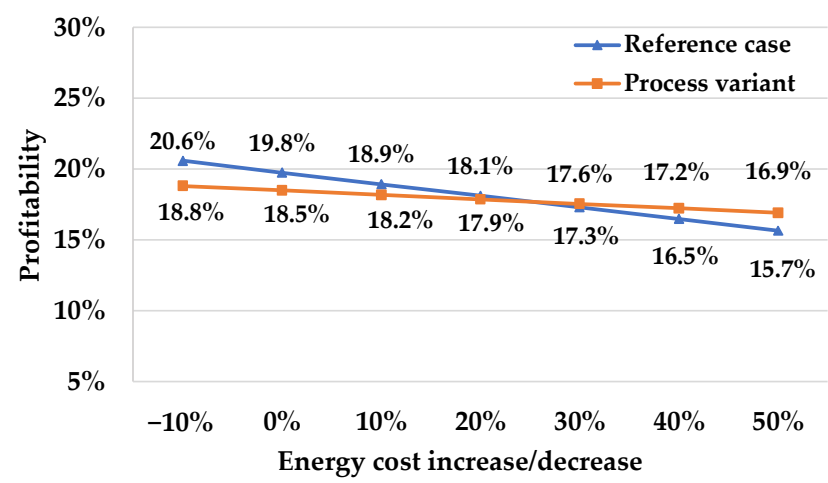

(a)

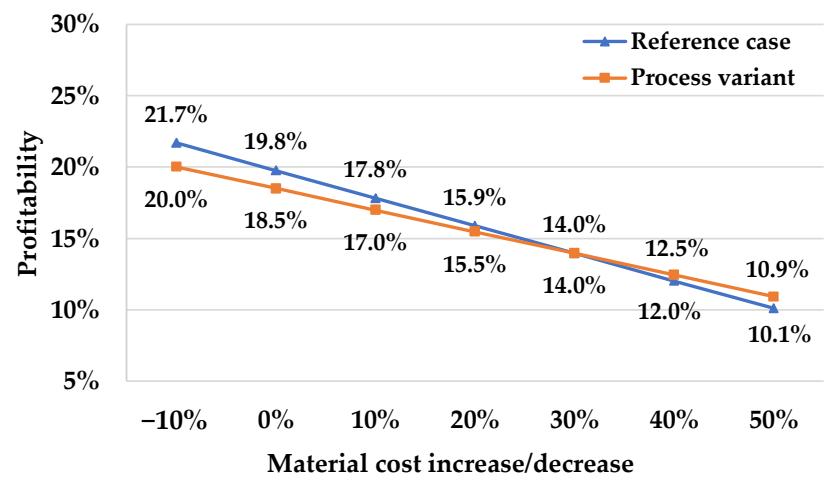

(b)

Figure 4. Sensitivity analysis: (a) energy costs; (b) material costs.

Because material costs are usually linked to energy costs, a variation between minus $10 \%$ and plus $50 \%$ was also considered here (see Figure $4 \mathrm{~b}$ ). Material costs have a much greater impact on profitability than energy costs. Here, as well, the reference variant is more affected by price increases. In the range considered, profitability decreases by about 11 percentage points for this variant and by almost 9 percentage points for the variant with 
an incineration plant. Even with a 50\% increase in material prices, profitability still remains above $10 \%$.

The sensitivity analysis also considered the case in which the biorefinery is operated in an industrial network. In this case, personnel capacities can be shared, and thus the proportional personnel costs can be reduced. Figure 5 a shows the influence of personnel costs. The basic calculations assume a self-sufficient operation of the plant with complete staffing. A range of plus 20 to minus 50\% was considered for the sensitivity analysis of personnel costs. An increase in personnel costs by $20 \%$ reduces profitability by about 5 to $6 \%$ in both variants. A $50 \%$ reduction in personnel costs increases profitability by 13 to $15 \%$, whereby the basic variant benefits more from lower personnel costs.

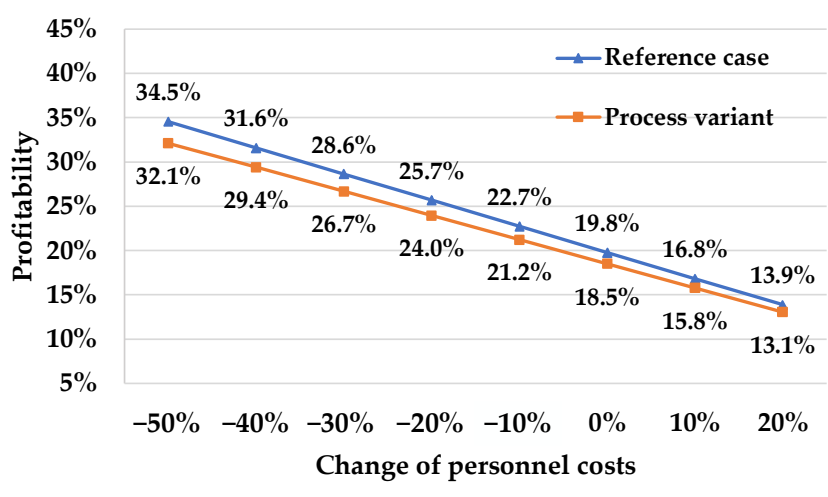

(a)

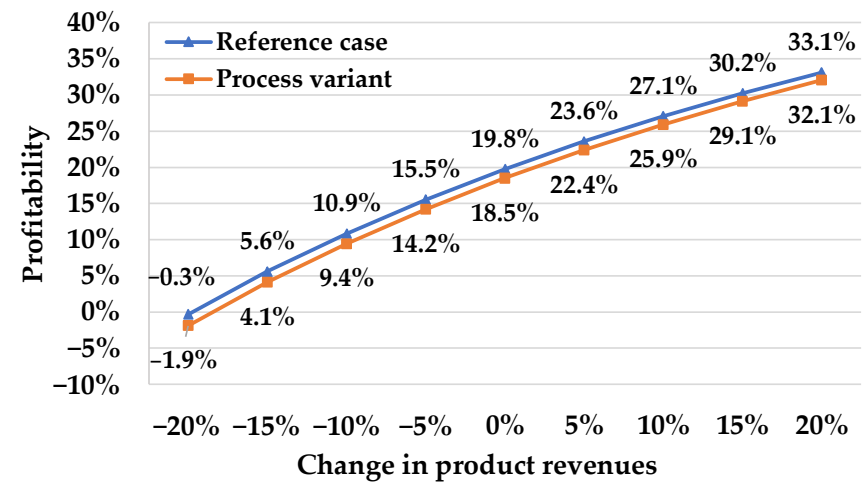

(b)

Figure 5. Sensitivity analysis: (a) personnel costs; (b) product revenues.

The market prices for the products produced have the greatest influence on the profitability of the plant (see Figure $5 b$ ). A variation of plus/minus $20 \%$ was considered for the cost block revenue. If total revenues fall by $20 \%$, then profitability also falls by approx. $20 \%$ for both variants. The process variant falls below $5 \%$ profitability earlier than the reference case because its values are generally about 1 to $1.5 \%$ lower. At a revenue decline of approximately $15 \%$, the plant reaches the $5 \%$ profitability threshold, and at a decline of $20 \%$, the plant runs at a loss. On the other hand, an increase in the revenue situation by $20 \%$ causes an increase in the return by about $13 \%$.

\subsection{Allocation of Costs to Products}

The first part of this publication series examined how the primary energy demand and $\mathrm{CO}_{2}$ emissions of the new biorefinery are distributed among the individual products generated. In this economic part of this publication series, an analysis was therefore made of how the operating costs of the plant are distributed among the individual products according to Ref. [47]. Such an analysis reveals whether all products provide a contribution margin or whether particularly profitable products have to compensate for less or non-profitable ones. For this allocation, a distribution of product volumes and another distribution of relative market values were generated from Table 2 . Torrefied biomass has the largest production mass share of all products at over $97 \%$, but it has the smallest share of the total market price per ton at $0.016 \%$. The torrefied biomass was set to an equivalent value of 1 due to its smallest market price share, and all other products were set relative to the market price share of this reference product. This results in an equivalence value of 5833 for the most expensive product 5-Hydroxymethylfurfural (5-HMF) which has a mass share of $0.0073 \%$ and a total market price share per ton of $93.84 \%$. The sales units can be calculated by multiplying the individual equivalent values by the annual output of each product. The total cost per year is then divided by the total number of sales units to obtain the total cost per sales unit, which is 0.1925 . The equivalence numbers can then be multiplied by the total cost per sales unit to determine the production costs for each product shown in blue in Figure 6. For instance, the equivalence value of 5-HMF is multiplied by 0.1925 to obtain a 
production price of $1123 €$. The thermal energy produced had to be related to the torrefied biomass, which is energetically recovered by combustion, in order to keep the relation to one unit $(\mathrm{kg} / \mathrm{h})$. The thermal energy is then allocated using the aforementioned method, which has a market price share of $0.031 \%$, nearly twice that of torrefied biomass. The allocation shows that all products provide a positive contribution to profit in the reference case as well as in the variant with incineration plant.

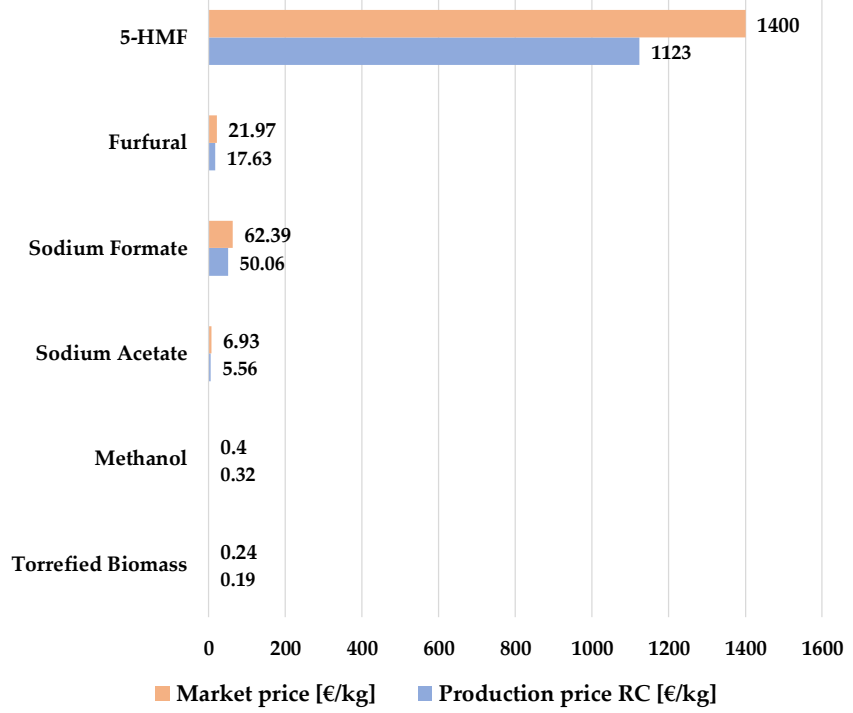

(a)

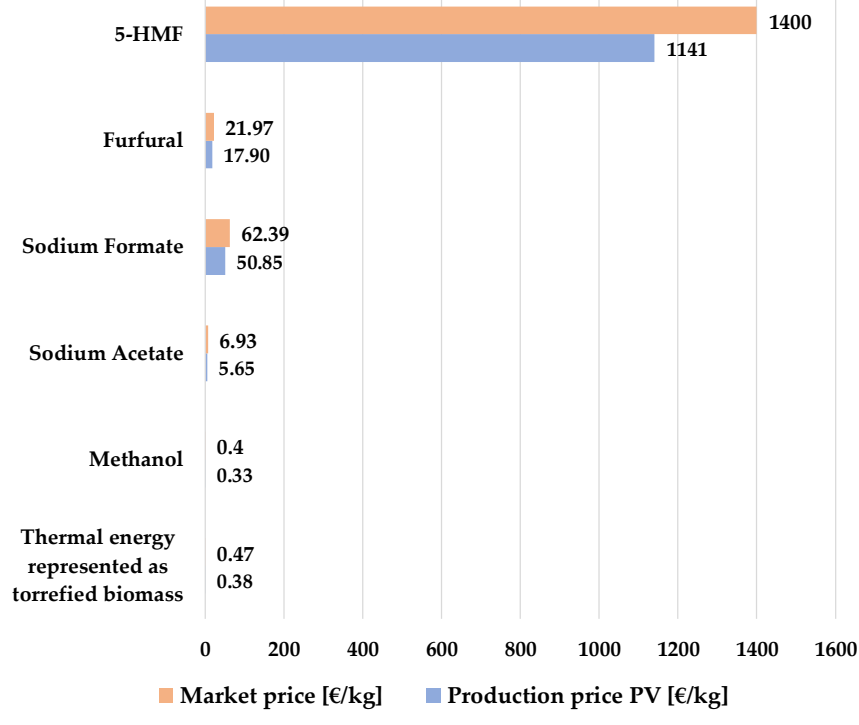

(b)

Figure 6. Cost allocation: (a) reference case; (b) process variant.

\subsection{Eco-Efficiency Analysis}

The results from the ecological analysis from the first part of this publication series were presented again for the operation of the biorefinery with beech woodchips in the form of a spider diagram for the reference case and the variant with biomass incineration in Figure 7a. The categories human toxicity (HTP), freshwater eutrophication (FEP) and freshwater ecotoxicity (FETP) are the same for both variants because only the biomass feedstock affects these three categories, and the operation with straw is not examined here.

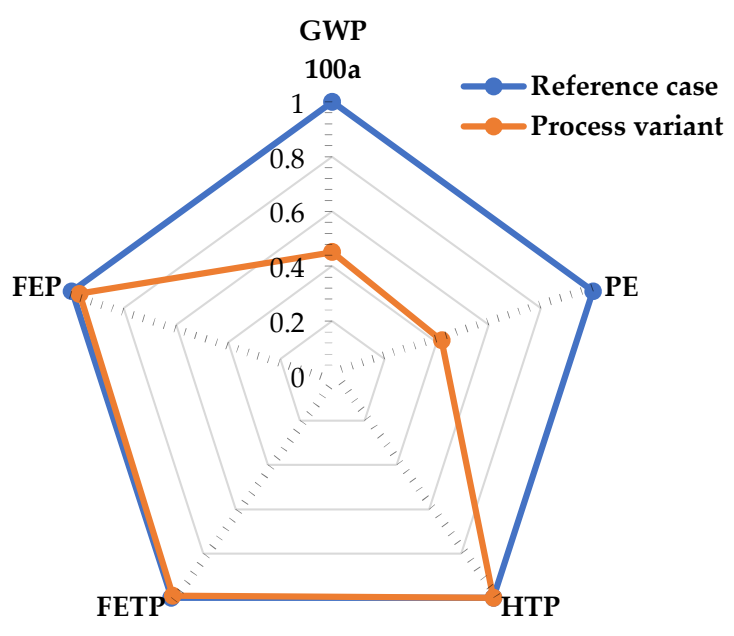

(a)

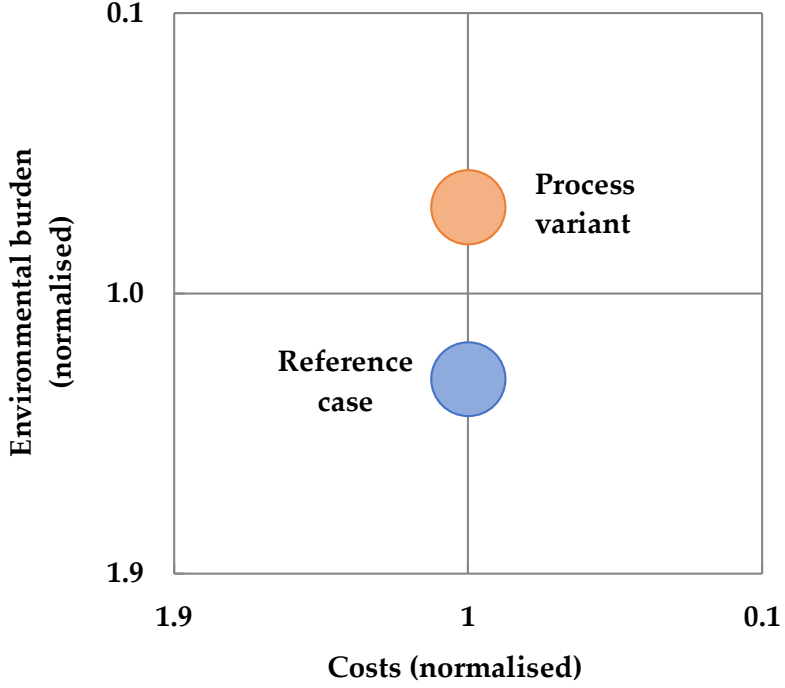

(b)

Figure 7. (a) normalised environmental effects; (b) eco-efficiency portfolio. 
Figure $7 \mathrm{~b}$ depicts the eco-efficiency portfolio of both operating variants considered. This profile was created according to references [48-50]. The values of the LCA and the sum of operating costs and revenues (indicated as "costs") are normalised in relation to each other, with the worst performance being assigned a value of 1 in each case. From this, the normalised mean values for the environmental impacts and the normalised mean values for the costs are calculated. Because there are five environmental impact categories, each must be weighted. Climate change (GWP) was weighted at $40 \%$, primary energy demand (PE) at 30\% and the remaining three at 10\% each. The individual results are then related to the mean value and multiplied by the individual weighting factors in the case of environmental impacts.

The normalised costs are 1.018 in the reference case and 0.982 in the variant with incineration plant, i.e., the process variant performs slightly poorer under the selected boundary conditions. However, with a value of 0.724 , the process variant performs significantly better in terms of environmental impacts than the reference case with 1.276.

\section{Derivation of Commercialisation Opportunities}

\subsection{Context}

In today's economy, fossil-based products set the economic standard. To be economically successful, biobased alternatives must offer at least the same quality and functionality as their conventional alternatives [7].

The bioeconomy is traditionally very strong in the food sector and in wood processing. However, it still has considerable growth potential in the economic sectors of construction materials, paper, textile fibres, chemicals, pharmaceuticals, heat, electricity and fuels [7]. In the processing sector, which currently still uses fossil carbon sources, biobased products have a potential for expansion (in some cases considerable) that goes far beyond the pure economic growth of these sectors [7].

Biobased products are in most cases more expensive than fossil carbon sources under current framework and market conditions. Due to the complex processing of biological raw materials, biobased alternatives are also less competitive than fossil-based products. Therefore, biobased products that are in direct competition with conventional alternatives can only be profitable in niche markets and only those that reward sustainability through price. For companies, this means adjusting their strategy, anticipating changing framework conditions at an early stage and adapting their product range accordingly [7]. Commercialisation opportunities for biorefineries may arise from the fact that new solutions and more sustainable alternatives are either mandated by regulations or demanded by customers [1] Biobased alternatives must be assessed on a case-by-case basis for their suitability compared to their conventional alternatives, and if no suitable products are available today, appropriate research efforts can be successful [7]. However, if products manufactured with fossil raw materials are burdened by taxation or an expansion of trading in emission certificates, this can change the competitive situation in favour of biorefineries [7].

The literature research carried out within this work does not allow for a sound quantitative representation of the market sizes of different markets and the competitive positions of biobased products from biorefineries. However, the following markets seem to be of special interest for the investigated biorefinery:

- Plastics, base and fine/speciality chemicals

- Pharmaceuticals

- Active carbon, synthetic fuels and others

- Energy markets (electricity, heat)

The review showed that currently the market development for the bioeconomy cannot be assessed so easily, especially because neither the industrial companies nor the markets examine biobased products separately. Only in the chemical and pharmaceutical industries are the possible developments more foreseeable [62]. 
The novel biorefinery studied here extracts a relatively small amount of high-value platform chemicals compared to the feedstock and produces a relatively large amount of high-quality torrefied biomass (see Figure 8).

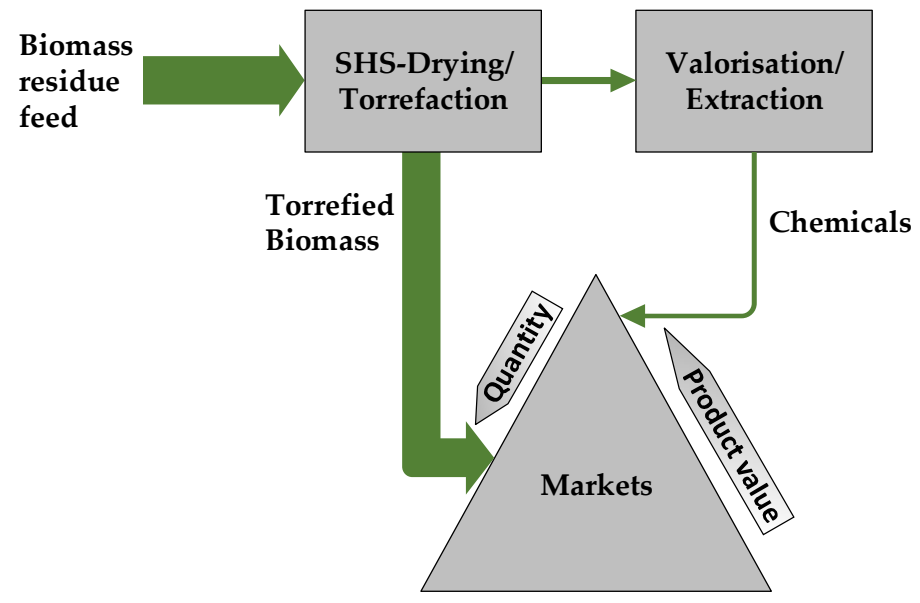

Figure 8. Biorefinery product-market-relationship.

Both product groups are interesting for different markets, which are discussed in the following.

\subsection{Markets for the Platform Chemicals}

Of particular importance in this development are biobased platform chemicals, bioplastics and biobased fine and speciality chemicals [62]. The chemical companies are most likely to see competitive advantages in biobased speciality chemicals and plan to focus more strongly here [62]. Chinese companies currently dominate the production and demonstration of marketable biobased products [62]. For biobased plastics, China, India and Southeast Asia are seen as the most important production locations of the future, and Brazil is also expanding its capacities [62]. The large chemical companies have little incentive to change the system towards biorefineries because they use proven, highly optimised technologies on a large scale, the infrastructure is built up and the process chains are established. The plants are often depreciated and therefore highly profitable [62]. Biobased chemical products are sold to the application-oriented industry, i.e., as intermediates. Market introduction was particularly successful when a "green premium" could be obtained for the intermediates [62,63].

Even though the use of renewable resources has only played a minor role in the pharmaceutical industry so far, innovative biotechnological approaches are of central importance for this branch of industry [62]. In Germany, a biopharmaceutical innovation system has been successfully established over the past decades and is networked with strong, internationally competitive players. A number of large companies and a significant and stable number of SMEs are active here and one finds a well-developed corporate landscape for biopharmaceutical activities [62].

The economic analysis shows that the investigated biorefinery can be operated economically under current market prices. However, the personnel costs and, in particular, the revenues must be viewed critically in terms of profitability.

The impact of personnel costs can be reduced by increasing the annual number of operating hours of the biorefinery and by integrating it into existing industrial networks.

The revenues from the sale of the products and demand must be considered volatile, especially for the extracted chemicals [11]. The quality and price of the chemicals produced must be kept at a high level to avoid jeopardising the economic viability of the plant. This means focusing on high quality products and even on application services for the speciality market rather than the mass market. Product and market diversification towards higher value products is seen as key for biorefineries to overcome commercialisation barriers [20]. 
These arguments are also supported by the fact that the plant concept of the biorefinery under investigation is not designed for large production volumes of chemicals and that biorefineries based on torrefaction for the production of mass products (biofuels) have not yet been successfully commercialised despite years of development with different approaches [15].

\subsection{Markets for the Torrefied Biomass}

The thermal integration of biorefineries in an internal or external production network promises a significant energy and economic improvement [31]. If heat integration is chosen, the optimal production capacity of the biorefinery can be matched to the demand of the consumers in the heat network [16]. These findings can also be transferred to the plant investigated here. Against the background of the results of the economic assessment, the optimal solution would be to integrate the investigated plant into an industrial network that already has its own heat supply or, in the best case, its own electricity generation. This would be particularly beneficial for the profitability of the investigated process variant and the ecological aspects.

The capacity of the biorefinery can be adapted so that it can best be integrated into an industrial symbiosis. It can be flexibly adapted in terms of the use of different biomass residues and energy recovery. In biorefineries that supply torrefied biomass as output, further processing by pyrolysis or gasification is possible in addition to thermal use through combustion. In this way, high quality products with technical advantages for iron production, adsorbents for environmental protection or feedstocks for the production of synthetic fuels can be generated [15].

\subsection{Biomass Supply}

An argument against mass production is the demand for biomass residues, which could possibly drive up prices. Long-term and the year-round availability of biomass at competitive prices is an important criterion for the operation of biorefineries. It is therefore advantageous if the plant can flexibly use several feedstocks per year depending on availability [13]. In the available studies on biomass torrefaction, different biomass materials have been used as feedstock. Lignocellulosic biomass and energy crops (e.g., bamboo, pine, spruce, willow, eucalyptus, banyan, larch, beech, birch, wood briquettes and wood pellets, etc.) are the most commonly used feedstocks. Torrefaction of agricultural residues and forestry wastes (e.g., sawdust, bagasse, coffee residues, rice husks and straw, wheat straw, empty fruit bunches from oil palms, etc.) has also been studied. However, special care is taken to ensure that there is no imbalance to the disadvantage of food supply and forest vegetation [15].

\subsection{Recommendations for Commercialisation}

A step-by-step approach for successful commercialisation in an open innovation system has proven to be viable to ensure resource mobilisation and market creation. Collaboration across the supply chain has proven to be beneficial because it can generate positive momentum. The innovation system must be able to mobilise the necessary resources while creating supply and demand [20].

As most business decisions are still made on the basis of the economic value of the main product in a value chain, awareness of value creation opportunities in alternative sectors is generally low from a marketing perspective. This is reinforced by the fact that costs and benefits of valorisation of biomass residues are assigned to different parties in the value chain. Therefore, new business models are needed that create an environment of equitable distribution of effort and benefit and that enable the development of innovative technologies across sectors [24]. It is important to involve public and private partners from the biomass supply sector and the end-product sector, and also to consider partners outside the value chain [64]. Typical customer-supplier relationships must be replaced by multi-actor relationships [24]. 
Therefore, a recommendation for the successful commercialisation of the investigated biorefinery concept is the operation of a flexibly usable demonstration plant in an open innovative network. The following sectors in particular should be considered as innovative partners for such a network, whereby the order does not represent a preference:

- Utilities with high innovation potential (e.g., from the municipal sector), which already have experience with the use of biomass

- Companies from the field of speciality chemicals, pharmaceuticals and food with a connection to the bioeconomy

- Innovative engineering companies with experience in biomass processing

- Consulting firms with roots in the bioeconomy and strong knowledge concerning supply chain aspects

- $\quad$ Start-ups and SMEs dedicated to application know-how and commercialisation aspects in the bioeconomy.

Companies from the paper industry or the large-scale chemical industry, for example, were deliberately not named because they are usually too entrenched in their existing structures and, after studying the state of the art, thus do not have the necessary innovation potential. On the other hand, they might be interested in buying green energy (heat or electricity) in the near future to reduce their carbon footprint and meet the new policy targets for $\mathrm{CO}_{2}$ emissions.

\section{Discussion}

\subsection{Economic Assessment}

The biorefinery investigated in this publication series fulfills both the ecological [41] and the economic sustainability criteria, provided that product revenues do not fall by more than $15 \%$ compared to the current market price level.

Both cost estimation methods used in this analysis lead to comparable investment costs. The depreciation over 20 years leads to reasonable annual fixed costs in the reference case. In the process variant, the necessary investment in an incineration plant leads to more than a doubling of the annual depreciation costs. In the process variant, the premiums for the indirect investment costs (such as infrastructure), for the process investment costs and the risk supplement, were reduced compared to the reference case. It is assumed that the incineration plant represents a high technical maturity level with low risk and is delivered as a pre-assembled unit that requires only minor additional investments in infrastructure compared to the reference case. A capital recovery factor over a 20-year lifetime is a common practice [16], especially for mature components such as silos, conveyors, fans, ductwork and the biomass incineration plant, which are used in the biorefinery in this case and account for the largest share of the costs. A reduction of the depreciation period of the investment costs to 15 years would nevertheless not endanger the profitability of the plant.

In the economic evaluation, it was assumed that the facility under investigation is operated as an independent enterprise and must therefore have complete staffing. Full staffing is a particular financial burden as it makes up in the investigated case for more than one third of the total costs (see Figure 3). The economic integration of the biorefinery into an industrial network would help to reduce the proportion of personnel costs and thus improve significant profitability (see Figure 5a).

The presented analyses of the newly developed biorefinery assumes an hourly processing capacity of $1000 \mathrm{~kg}$ of biomass and an annual operating time of $5080 \mathrm{~h}$. Because the fixed costs in the reference case and in the process variant account for 66 and $77.5 \%$ of the total operating costs, respectively, the annual operating time has a significant influence on profitability. An increased annual operating time raises the variable operating costs, but higher revenues are generated and the proportion of fixed costs is reduced.

The costs for the biomass residue raw material represent the second largest cost block in both variants after the personnel costs. These costs can be decreased significantly if low value feedstock, such as residues from forestry activities, is used. However, an increase in 
procurement costs has a significantly lower impact on the profitability of the plant than personnel costs (see Figure 4b).

The biorefinery has been significantly optimised in terms of energy as part of the process development to date, and the process variant allows fossil fuels to be abandoned for heat generation. The variation in energy costs has little effect on profitability in the reference case $(<5 \%)$ and very little effect in the process variant $(<2 \%)$ within the considered price range of -10 to $+50 \%$ (see Figure $4 a$ ).

From the output side, two different categories of products must be delineated. Almost $70 \%$ of the input material is converted into torrefied biomass with a lower monetary specific value and just under $2 \%$ into platform chemicals with a high monetary specific value. In the scenarios considered, the torrefied biomass is made available as a high-grade fuel in the reference case or as feedstock for upgrading to activated carbon, synthesis gas or synthetic fuel. In the variant with incineration plant, the torrefied biomass covers the biorefinery's own thermal energy demand and provides a significant amount of thermal energy for external customers.

Given today's market prices for torrefied biomass and for thermal energy, between 38 and $52 \%$ of total revenues are generated directly from torrefied biomass or indirectly through thermal energy sales. Due to the small plant size, the sales volume of torrefied biomass or thermal energy is considered small, which can be seen as an advantage for the integration into existing industrial networks. The design of the dryers and the torrefaction systems is modular ( $250 \mathrm{~kg} / \mathrm{h}$ input per unit). This means that the plant can be designed precisely to meet the needs of industrial consumers. Because heat with a temperature of up to $270{ }^{\circ} \mathrm{C}$ is generated, it could possibly be sold at a higher price than is currently assumed (7.5 Eurocents $/ \mathrm{kWh}$ ), which would increase the profitability of the biorefinery.

Due to their small quantities, the extracted platform chemicals can be viewed in isolation from the torrefied biomass produced concerning the plant design, the location of the extraction process steps and the market for chemicals. More than 20 extractable chemicals were identified in the experiments with beech wood chips. However, only five currently attractive chemicals were explicitly included in the present economic study. Further studies need to show what other chemicals can be extracted if other biomass residues are used and what prices may be obtained for them. With the values taken in this study, the platform chemicals contribute more than $60 \%$ to the value generation in the reference case and $48 \%$ in the variant with an incineration plant.

In the ideal case, customers from the chemical (speciality and fine chemicals), pharmaceutical, cosmetic or other specialty industries would be in direct local connection with the biorefinery. However, due to the small production volumes and the high value of the extracted chemicals, the transport costs for these play a subordinate role. In other words, the customers for the platform chemicals can be further away.

By varying the feedstock, temperature and residence time in the torrefaction chamber, the output of potential chemicals can be altered. This means that with the choice of biomass feedstocks used and the variation of plant parameters, one can flexibly extract different value-added chemicals and thus respond flexibly to market changes. The literature review has shown that the flexibility of a biorefinery in respect to constantly changing markets and the products that are in particular demand is a very important commercialisation success factor.

Product revenues have the greatest influence on the profitability of the plant in the biorefinery studied in this paper. Therefore, a commercialisation strategy for the platform chemicals must pay special attention to primarily serving the high-quality and thus highpriced customer segment and not the low-priced mass market. The platform chemicals produced are usually needed for intermediate products. This requires a high degree of flexibility and application know-how. Therefore, the revenues generated should be invested in application-oriented research efforts that focus not only on the further technical development of the plant, but also on possible new market applications. The increase in product revenue also has the greatest impact on the return on investment (ROI) and the 
payback period (PP). With the basic assumptions made, the annualised ROI for the reference case is $24.6 \%$ and the PP 4.4 years (process variant $22.7 \%$ and 7.8 years, respectively). If revenues can be increased by $20 \%$, the annualised $\mathrm{ROI}$ in the reference case is $49.5 \%$ and the PP is 2.2 years (process variant $47.2 \%$ and 3.75 years, respectively).

All six biorefinery products investigated in this work deliver a positive financial contribution to the result. For further extractable substances, however, it would have to be examined whether this statement is still valid, especially if further process steps have to be installed for this purpose. $\mathrm{CO}_{2}$ credits were not included in the economic analysis because this requires government authorisation to participate in emissions trading. These alone would only marginally improve profitability, because the costs for primary energy account for just $10 \%$ of the total operating costs in the reference case examined and merely $4 \%$ in the process variant.

In the eco-efficiency analysis, both variants examined with the assumptions made perform almost equally on the economic side. However, the process variant with biomass incineration plant and thermal self-supply performs significantly better ecologically than the reference case. In the case of an industrial symbiosis, participation in emissions trading and/or rising material and energy prices, the process variant benefits from economic performance and then moves into the best area of the eco-efficiency portfolio compared to the reference case. The present eco-efficiency analysis should be seen as a basis from which to review the eco-efficiency portfolio for concrete implementation cases within the framework of an industrial symbiosis. For this purpose, other environmental impacts such as particulate matter may have to be added.

\subsection{Commercialisation Aspects}

Against the background of the information gathered from the literature review and the economic analysis carried out, it seems advisable to realise the demonstration operation as well as the commercialization of the biorefinery in an open innovation environment. The possible separation of biomass pre-treatment and extraction of different platform chemicals from the condensate facilitates the participation of different types of actors in the open innovation network.

The literature research has shown that traditional players find it difficult to adapt their more or less proven traditional way of thinking to the new conditions of a circular economy and constantly changing market conditions. This is especially true when these players have served large market volumes at low prices, but rising energy prices and current climate policy could change this behaviour in the future. Nevertheless, it is important for the network and commercialisation of the biorefinery to involve innovative, knowledge gap closing and application-oriented actors especially from the fields of speciality and fine chemicals, the pharmaceutical, cosmetic and bioeconomy sectors as shown in Figure 9. The network's external recognition must be strong enough to attract and embrace further innovative actors, e.g., from the utility sector. This also means that the open innovation system must be designed in such a way that it can develop continuously. If robust industrial symbiosis can be developed within the network, this will have a positive impact on the profitability of the biorefinery, as infrastructure and personnel can be shared.

In order to trigger the necessary investments, it is necessary either to obtain state funding or to attract financially strong actors. This will also raise the question of how the profits will be distributed fairly in the network and who will take over the project management at which point in time. Against the background of these challenges, it makes sense to take a closer look at existing open innovation platforms from other industrial sectors, such as ARENA 2036 [65], for the mobility and production of the future, or to join a platform from the bioeconomy sector, such as TALENT4BBI [66]. 


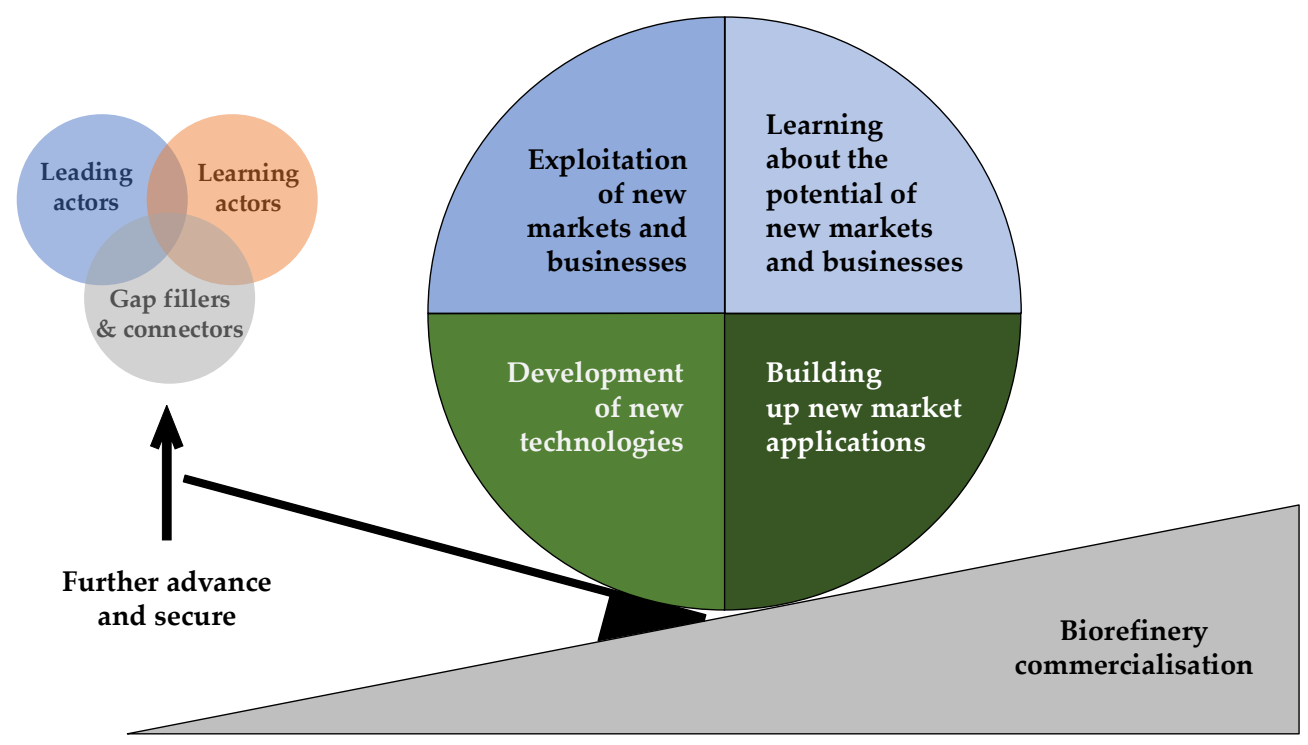

Figure 9. Biorefinery commercialisation proposal.

\section{Conclusions}

The economic analysis of the investigated novel biorefinery shows that it can be operated economically under the current conditions and the assumptions made. Because the plant is small compared to the conventional production capacities, the infrastructure and personnel costs are disproportionately high. However, the plant size can be increased if enough feedstock is available. Moreover, this dilemma can be solved if the biorefinery is used as part of a production network and the above-mentioned costs only have to be charged in part. Selling the surplus heat has little impact on profitability but makes it independent from the purchase of natural gas, which is more environmentally friendly and interesting for a sustainable industrial symbiosis. Focusing on niche markets that are willing to pay a higher price for high-quality chemicals is crucial for the profitability of the biorefinery operation. The plant size, the structure and the flexibility of the biorefinery in terms of the biomass feedstock, the mode of operation and the generated products are advantageous for an industrial symbiosis. The different, flexibly generated products make the biorefinery interesting for a variety of different industries. The plant is at the development stage between laboratory and demonstration scale and has yet to be established in the circular economy environment. It would therefore make sense to carry out further development and commercialisation within the context of an open innovation platform. Such a platform would allow different actors to participate in the project, and hence, valuable synergies could be leveraged. In summary, the flexibility of the plant, its low complexity and the focus on niche markets are a good basis for the sustainability, competitiveness and resilience of the novel biorefinery.

The investigated biorefinery is ecologically and economically very well suited to support the achievement of the 2030 target for the reduction in greenhouse gas emissions as well as the target of climate neutrality by 2050 within the framework of the European Green Deal. It is also appropriate for realising the shift from linear economy to circular economy value chains.

The successful upscaling and implementation of the developed biorefinery concept will depend on the ability to treat different types of feedstock/residues, the automatic and robust operation of the different processes (with reduced staff intervention) and the market demand of the obtained products. Therefore, further works will focus on the continuous separation of chemicals, the flexible extraction of different valorisation products and the upscaling of the SHS-based drying/torrefaction with different biomass residues. 
Supplementary Materials: The following are available online at https: / www.mdpi.com/article / 10.3390/su14042338/s1, Direct investment costs for Reference Case and Process Variant.

Author Contributions: Conceptualization, B.R., P.K.-M. and A.D.; methodology, P.K.-M.; software, B.R.; validation, B.R.; formal analysis, B.R. and P.K.-M.; investigation, B.R.; resources, P.K.-M.; data curation, B.R.; writing-original draft preparation, B.R. and P.K.-M.; writing-review and editing, P.K.-M. and A.D.; visualization, B.R. and P.K.-M.; supervision, P.K.-M.; project administration, P.K.-M.; funding acquisition, P.K.-M. and A.D. All authors have read and agreed to the published version of the manuscript.

Funding: This research was funded by the FEDERAL MINISTERY OF EDUCATION AND RESEARCH (BUNDESMINISTERIUM FÜR BILDUNG UND FORSCHUNG), grant number 031B0664.

Institutional Review Board Statement: Not applicable.

Informed Consent Statement: Not applicable.

Data Availability Statement: Data are contained within the article or Supplementary Material.

Conflicts of Interest: The authors declare no conflict of interest.

\section{References}

1. D'Amato, D.; Veijonaho, S.; Toppinen, A. Towards sustainability? Forest-based circular bioeconomy business models in Finnish SMEs. For. Policy Econ. 2018, 110, 101848. [CrossRef]

2. Vu, H.P.; Nguyen, L.N.; Vu, M.T.; Johir, M.A.H.; McLaughlan, R.; Nghiem, L.D. A comprehensive review on the framework to valorise lignocellulosic biomass as biorefinery feedstocks. Sci. Total. Environ. 2020, 743, 140630. [CrossRef] [PubMed]

3. Cheah, W.Y.; Sankaran, R.; Show, P.L.; Ibrahim, T.N.B.T.; Chew, K.W.; Culaba, A.; Chang, J.-S. Pretreatment methods for lignocellulosic biofuels production: Current advances, challenges and future prospects. Biofuel Res. J. 2020, 7, 1115-1127. [CrossRef]

4. Hilz, X. Assessing Areas of Concern in the Commercialisation Process of Biorefineries: An Importance Performance Analysis. Master's Thesis, Universität Graz, Graz, Austria, 2021.

5. Reim, W.; Sjödin, D.; Parida, V.; Rova, U.; Christakopoulos, P. Bio-economy based business models for the forest sector-A systematic literature review. In Proccedings of International Scientific Conference "Rural Development 2017", Kaunas, Lithuania, 22 December 2017; Aleksandras Stulginskis University: Kaunas, Lithuania, 2017. [CrossRef]

6. Domínguez-Robles, J.; Cárcamo-Martínez, Á.; Stewart, S.A.; Donnelly, R.F.; Larrañeta, E.; Borrega, M. Lignin for pharmaceutical and biomedical applications-Could this become a reality? Sustain. Chem. Pharm. 2020, 18, 100320. [CrossRef]

7. Kircher, M. Bioökonomie im Selbststudium: Unternehmensstrategie und Wirtschaftlichkeit; Springer: Berlin/Heidelberg, Germany, 2020; ISBN 978-3-662-61004-6.

8. Orive, M.; Cebrián, M.; Amayra, J.; Zufía, J.; Bald, C. Techno-economic assessment of a biorefinery plant for extracted olive pomace valorization. Process Saf. Environ. Prot. 2021, 147, 924-931. [CrossRef]

9. Hansen, T.; Coenen, L. Unpacking resource mobilisation by incumbents for biorefineries: The role of micro-level factors for technological innovation system weaknesses. Technol. Anal. Strat. Manag. 2016, 29, 500-513. [CrossRef]

10. Wang, Y. Development of a Quantitative Risk Analysis Approach to Evaluate the Economic Performance of an Industrial-Scale Biorefinery; University of British Columbia: Vancouver, BC, Canada, 2018.

11. Elaradi, M.B.; Zanjani, M.K.; Nourelfath, M. Integrated forest biorefinery network design under demand uncertainty: A case study on canadian pulp \& paper industry. Int. J. Prod. Res. 2021, 59, 1-19. [CrossRef]

12. Chai, L.; Saffron, C.M. Comparing pelletization and torrefaction depots: Optimization of depot capacity and biomass moisture to determine the minimum production cost. Appl. Energy 2016, 163, 387-395. [CrossRef]

13. Chandel, A.K.; Garlapati, V.K.; Singh, A.K.; Antunes, F.A.F.; Da Silva, S.S. The path forward for lignocellulose biorefineries: Bottlenecks, solutions, and perspective on commercialization. Bioresour. Technol. 2018, 264, 370-381. [CrossRef]

14. Kaserer, W. Fasern für fast alles im Leben. In CSR und Klimawandel; Sihn-Weber, A., Fischler, F., Eds.; Springer: Berlin/Heidelberg, Germany, 2020; pp. 381-393; ISBN 978-3-662-59747-7.

15. Chen, W.-H.; Lin, B.-J.; Lin, Y.-Y.; Chu, Y.-S.; Ubando, A.T.; Show, P.L.; Ong, H.C.; Chang, J.-S.; Ho, S.-H.; Culaba, A.B.; et al. Progress in biomass torrefaction: Principles, applications and challenges. Prog. Energy Combust. Sci. 2020, 82, 100887. [CrossRef]

16. Zetterholm, J. Evaluation of Emerging Forest-Industry Integrated Biorefineries: Exploring Strategies for Robust Performance in Face of Future Uncertainties. Ph.D. Thesis, Lulea University of Technology, Lulea, Sweden, 2021.

17. Lager, T.; Blanco, S.; Frishammar, J. Managing R\&D and innovation in the process industries. RED Manag. 2013, 43, 189-195. [CrossRef]

18. Mossberg, J.; Frishammar, J.; Söderholm, P.; Hellsmark, H. Managerial and organizational challenges encountered in the development of sustainable technology: Analysis of Swedish biorefinery pilot and demonstration plants. J. Clean. Prod. 2020, $276,124150$. [CrossRef] 
19. Tsvetanova, L.; Carraresi, L.; Wustmans, M.; Bröring, S. Actors' strategic goals in emerging technological innovation systems: Evidence from the biorefinery sector in Germany. Technol. Anal. Strat. Manag. 2021, 33, 1-14. [CrossRef]

20. Kasnitz, L. Building a Biorefinery Business: If it does not Fit, Make it Fit—Strategies for Successful Commercialization. Master's Thesis, Lund University, Lund, Sweden, 2017.

21. Musiolik, J.; Markard, J.; Hekkert, M.; Furrer, B. Creating innovation systems: How resource constellations affect the strategies of system builders. Technol. Forecast. Soc. Chang. 2020, 153, 119209. [CrossRef]

22. Budzianowski, W.M. High-value low-volume bioproducts coupled to bioenergies with potential to enhance business development of sustainable biorefineries. Renew. Sustain. Energy Rev. 2017, 70, 793-804. [CrossRef]

23. Odegard, I.; Croezen, H.; Bergsma, G. Cascading of Biomass: 13 Solutions for a Sustainable Bio-Based Economy. Making Better Choices for Use of Biomass Residues, by-Products and Wastes. Available online: https://ce.nl/wp-content/uploads/2021/03/ CE_Delft_2665_Cascading_of_Biomass_def_1348490086.pdf (accessed on 12 November 2021).

24. Donner, M.; Gohier, R.; de Vries, H. A new circular business model typology for creating value from agro-waste. Sci. Total Environ. 2020, 716, 137065. [CrossRef]

25. Ahlström, J. Shaping Future Opportunities for Biomass Gasification: The Role of Integration. Ph.D. Thesis, Chalmers University of Technology, Gothenburg, Sweden, 2020.

26. Hassan, S.S.; Williams, G.A.; Jaiswal, A.K. Lignocellulosic Biorefineries in Europe: Current State and Prospects. Trends Biotechnol. 2019, 37, 231-234. [CrossRef]

27. Gabriella, N. A Delphi Study of Factors Affecting Forest Biorefinery Development in the Pulp and Paper Industry: The Case of Bio-Based Products. Master's Thesis, Universität Graz, Graz, Austria, 2016.

28. Arora, A.; Banerjee, J.; Vijayaraghavan, R.; MacFarlane, D.; Patti, A. Process design and techno-economic analysis of an integrated mango processing waste biorefinery. Ind. Crop. Prod. 2018, 116, 24-34. [CrossRef]

29. Nitzsche, R.; Budzinski, M.; Gröngröft, A.; Majer, S. Bewertungsansätze bei der Optimierung von Bioraffinerie-Konzepten. In Bioenergie. Vielseitig, Sicher, Wirtschaftlich, Sauber?! Nelles, M., Ed.; DBFZ Deutsches Biomasseforschungszentrum Gemeinnützige GmbH: Leipzig, Germany, 2014; pp. 57-68. ISBN 2199-9384.

30. Wilén, C.; Sipilae, K.; Tuomi, S.; Hiltunen, I.; Lindfors, C.; Sipilä, E.; Saarenpää, T.-L.; Raiko, M. Wood Torrefaction: Market Prospects and Integration with the Forest and Energy Industry. Available online: https://www.vttresearch.com/sites/default/ files/pdf/technology/2014/T163.pdf (accessed on 11 November 2021).

31. Hagberg, M.B.; Pettersson, K.; Ahlgren, E.O. Bioenergy futures in Sweden-Modeling integration scenarios for biofuel production. Energy 2016, 109, 1026-1039. [CrossRef]

32. Ahlström, J.M.; Pettersson, K.; Wetterlund, E.; Harvey, S. Value chains for integrated production of liquefied bio-SNG at sawmill sites-Techno-economic and carbon footprint evaluation. Appl. Energy 2017, 206, 1590-1608. [CrossRef]

33. Arvidsson, M.; Heyne, S.; Morandin, M.; Harvey, S. Integration Opportunities for Substitute Natural Gas (SNG) Production in an Industrial Process Plant. Available online: https:/ / www.aidic.it/cet/12/29/056.pdf (accessed on 11 November 2021).

34. Budzianowski, W.M.; Postawa, K. Total Chain Integration of sustainable biorefinery systems. Appl. Energy 2016, 184, 1432-1446. [CrossRef]

35. Hellsmark, H.; Hansen, T. A new dawn for (oil) incumbents within the bioeconomy? Trade-offs and lessons for policy. Energy Policy 2020, 145, 111763. [CrossRef]

36. Cesena, E.A.M.; Mutale, J.; Rivas-Davalos, F. Real options theory applied to electricity generation projects: A review. Renew. Sustain. Energy Rev. 2013, 19, 573-581. [CrossRef]

37. Horst, S.; Höfer, J.; Kleine-Möllhoff, P.; Wennagel, F.; Wiech, N.; Pfost, M.; Atmaca, B.; Gries, J.; Epple, R. Kostenkalkulation im Anlagenbau: Modell zur Bewertung der Konkurrenzfähigkeit im Entwicklungsstadium. Chem. Ing. Tech. 2020, 92, 1033-1043. [CrossRef]

38. Humphreys, K.K. Project and Cost Engineers Handbook, 4th ed.; Marcel Dekker: New York, NY, USA, 2004. [CrossRef]

39. Albaroudi, H.; Atayi, K.; Baleka, K.; Osae, E.; Pushparakan, S.; Taylor, A. Acetic Acid Process Plant Design; University of Hull: Hull, UK, 2016.

40. Prinzing, P.; Rödl, R.; Aichert, D. Investitionskosten-Schätzung für Chemieanlagen. Chem. Ing. Tech. 1985, 57, 8-14. [CrossRef]

41. Roy, B.; Kleine-Möllhoff, P.; Dalibard, A. Superheated Steam Torrefaction of Biomass Residues with Valorisation of Platform Chemicals-Part 1: Ecological Assessment. Sustainability 2022, 14, 1212. [CrossRef]

42. Castedello, M.; Schöninger, S. Cost of Capital Study 2020: Global Economy-Search for Orientation? Available online: https://hub.kpmg.de/kapitalkostenstudie-2020?utm_campaign=Kapitalkostenstudie\%202020\&utm_source=AEM (accessed on 29 September 2021).

43. Norder Band, A.G. Legierungszuschlag.info: Legierungszuschlag für Werkstoff 1.4301. Available online: https:/ / legierungszuschlag. info/wkst/4301 (accessed on 6 July 2021).

44. Janisch, A. Kostenfaktoren im Stahlbau: Was Kostet ein kg Stahlbau 2021? Available online: https://jactio.com/kostenfaktorenim-stahlbau / (accessed on 4 November 2021).

45. CheCalc. Shortcut Heat Exchanger Sizing. Estimates LMTD, Exchanger Surface Area, Number of Tubes, Shell Diameter and Number of Shell in Series. Available online: https:/ / checalc.com/calc/ShortExch.html (accessed on 26 January 2022).

46. Eltrop, L. Leitfaden Feste Biobrennstoffe, Gülzow-Prüzen. 2014. Available online: http://www.fnr.de/fileadmin/allgemein/pdf/ broschueren/leitfadenfestebiobrennstoffe_web.pdf (accessed on 1 October 2021). 
47. Horsch, J. Kostenrechnung: Klassische und neue Methoden in der Unternehmenspraxis, 3rd ed.; Springer Fachmedien Wiesbaden: Wiesbaden, Germany, 2018; ISBN 978-3-658-20029-9.

48. Ingenieure, V.D. Methods for Evaluation of Waste Treatment Processes: Part 2, Samples Calculations; VDI 3925 Part 2; Beuth Verlag: Berlin, Germany, 2018.

49. Saling, P.; Kicherer, A.; Dittrich-Krämer, B.; Wittlinger, R.; Zombik, W.; Schmidt, I.; Schrott, W.; Schmidt, S. Eco-efficiency analysis by basf: The method. Int. J. Life Cycle Assess. 2002, 7, 203-218. [CrossRef]

50. Rüdenauer, I.; Grießhammer, R.; Bunke, D.; Gensch, C. Integrated Environmental and Economic Assessment of Products and Processes. J. Ind. Ecol. 2005, 9, 105-116. [CrossRef]

51. Statista. Annual Electricity Prices (Including Electricity Tax) for Industrial Businesses in Germany from 1998 to 2021 : (In Euro Cents per Kilowatt Hour). Available online: https: / www.statista.com/statistics/1050448/industrial-electricity-prices-includingtax-germany / (accessed on 18 January 2022).

52. Statista. Gaspreise* für Gewerbe- und Industriekunden in Deutschland in den Jahren 2011 bis 2021: (In Euro-Cent pro Kilowattstunde). Available online: https://de.statista.com/statistik/daten/studie/168528/umfrage/gaspreise-fuer-gewerbe-undindustriekunden-seit-2006/\#: \{\}:text=Zum\%201.,2\%2C95\%20Cent\%20pro\%20Kilowattstunde (accessed on 18 January 2022).

53. Centrale Agrar-Rohstoff Marketing- und Energie-Netzwerk. Marktpreise Pellets. Available online: https://www.carmen-ev.de/ service/marktueberblick/marktpreise-energieholz/marktpreise-pellets/ (accessed on 10 January 2022).

54. AGFW I Der Effizienzverband für Wärme, Kälte und KWK e.V; Statistik Fernwärme: Preisübersicht, Frankfurt am Main, Germany, 2020; Available online: https: / / www.agfw.de/index.php?eID=tx_securedownloads\&p=345\&u=0\&g=0\&t=1640739723 \&hash=a7afb9b043c6373adbd36969041eb8fe0ef7f864\&file=/fileadmin/user_upload/Wirtschaft_u_Markt/markt_und_preise / Preisbildung-_Anpassung/2020_AGFW_Preisuebersicht_Webexemplar.pdf (accessed on 1 October 2021).

55. Breitkopf, A. Durchschnittlicher Preis für Methanol auf dem Europäischen Markt in den Jahren von 2012 bis 2021. Available online: https: / de.statista.com/statistik/daten/studie/730823/umfrage/durchschnittlicher-preis-fuer-methanol-auf-demeuropaeischen-markt/ (accessed on 7 June 2021).

56. Roth, C. Natriumacetat Trihydrat, 25 kg, $\geq 99 \%$, Ph. Eur., USP. Available online: https://www.carlroth.com/de/de/von-a-bis-z/ natriumacetat-trihydrat/p/3856.5 (accessed on 7 June 2021).

57. Roth, C. Natriumformiat, $1 \mathrm{~kg}$, $\geq 99 \%$, p.a., ACS. Available online: https://www.carlroth.com/de/de/natriumsalze-na/ natriumformiat/p/4404.3 (accessed on 7 June 2021).

58. Aldrich, S. Furfural for Synthesis: 98-01-1. Available online: https://www.sigmaaldrich.com/DE/en/product/mm/804012 (accessed on 26 January 2022).

59. Aldrich, S. Furfural, $\geq 98 \%$, FCC, FG: W248908-25KG-K. Available online: https://www.sigmaaldrich.com/DE/en/product/ aldrich/w248908 (accessed on 26 January 2022).

60. Aldrich, S. Furfural, Natural, $\geq 98 \%$, FCC, FG: W248924-10KG-K. Available online: https://www.sigmaaldrich.com/DE/ en/product/aldrich/w248924?gclid=Cj0KCQjwqp-LBhDQARIsAO0a6aIH_8uFG_r4gPO_Df_vJMdpAFRMJvyEiDR5Cfq0 wiiAdlot-Vq77ioaAlkREALw_wcB (accessed on 26 January 2022).

61. Scott, G. Marktpreise Plattformchemikalien; AVA Biochem: Zug, Switzerland, 2021.

62. Zinke, H.; El-Chichakli, B.; Dieckhoff, P.; Wydra, S.; Hüsing, B. Bioökonomie für Die Industrienation: Ausgangslage für Biobasierte Innovationen in Deutschland Verbessern, Berlin. 2016. Available online: https://www.biooekonomierat.de/ fileadmin/Publikationen/berichte/Hintergrundpapier_ISA_Vero_ffentlichung_2.pdf (accessed on 17 September 2021).

63. Carus, M.; Raschka, A.; Piotrowski, S. Entwicklung von Förderinstrumenten für die Stoffliche Nutzung von Nachwachsenden Rohstoffen in Deutschland (Kurzfassung): Volumen, Struktur, Substitutionspotenziale, Konkurrenzsituation und Besonderheiten der Stofflichen Nutzung Sowie Entwicklung von Förderinstrumenten, Mai 2010 = The Development of Instruments to Support the Material Use of Renewable Raw Materials in Germany (Summary), 2., Geringfügig Überarb. Aufl., Juli 2010; Nova-Institut für Politische und Ökologische Innovation GmbH: Hürth, Germany, 2010; ISBN 9783981202731.

64. Rakotovao, M.; Gobert, J.; Brullot, S. Bioraffineries rurales: La question de l'ancrage territorial. GeoCantemir 2017, 44, 85-100. [CrossRef]

65. Froeschle, P.; ARENA2036: The Research Campus. The Innovation Platform for Mobility and Production of the Future. Available online: https:/ / www.arena2036.de/en/ (accessed on 17 November 2021).

66. The European Bioeconomy Network. TALENT4BBI: Training Future Leaders 4 the European Bio-Based Industries. Available online: https:/ / eubionet.eu/category/projects/open-innovation-platforms-and-facilities/ (accessed on 17 November 2021). 